\title{
A new species of Zamischus (Hymenoptera, Cynipoidea, Figitidae) from Brazil
}

\author{
Norma Díaz¹, Fabiana Gallardo', Cecilia Dorfey² \& Andreas Köhler ${ }^{2}$ \\ 'División Entomología, Facultad de Ciencias Naturales y Museo, UNLP, Paseo del Bosque s/n, 1900 La Plata, Buenos Aires, Argentina. \\ ndiaz@fcnym.unlp.edu.ar \\ ${ }^{2}$ Laboratório de Entomologia, Universidade de Santa Cruz do Sul, Av. Independência 2293, Bairro Universitário, 96815-900 Santa Cruz do Sul-RS, \\ Brazil.andreas@unisc.br
}

\begin{abstract}
A new species of Zamischus (Hymenoptera, Cynipoidea, Figitidae) from Brazil. A new species of Zamischus from Brazil is described and diagnosed. The species is closely related to $Z$. brasiliensis but differs in the morphology of antennae and scutellum. Z. aquilesi sp. nov. was collected via Malaise trapping in a tobacco field in Santa Cruz do Sul, Rio Grande do Sul.

KEYWORDS. Brazil; Cynipoidea; Eucoilinae; Figitidae.

RESUMO. Uma nova espécie de Zamischus (Hymenoptera, Cynipoidea, Figitidae) do Brasil. Uma nova espécie de Zamischus do Brasil é descrita e diagnosticada. A espécie é intimamente relacionada a Z. brasiliensis, mas difere na morfologia da antena e do escutelo. Z. aquilesi sp. nov. foi coletada com armadilha de Malaise em uma lavoura de tabaco em Santa Cruz do Sul, Rio Grande do Sul.
\end{abstract}

PALAVRAS-CHAVE: Brasil; Cynipoidea; Eucoilinae; Figitidae.

Species of Zamischus Ashmead are minute, stick-like wasps, which belong to the parasitic Eucoilinae, the richest and most diverse subfamily of Figitidae in the Neotropical Region (Díaz et al. 2008). This genus was proposed by Ashmead (1903a) with the type-species, Z. brasiliensis Ashmead, 1903, designated, but not described. Weld (1921) described and illustrated the type-species, which he later added to his key to the world genera of Cynipoidea (Weld 1952). Yoshimoto (1971) described Z. elongatus Yoshimoto, 1971 and the male of $Z$. brasiliensis. Later Díaz (1974) recorded Z. brasiliensis from Argentina. The two known species of Zamischus are from South America. The purpose of this study is to describe a new species of this genus collected in a tobacco field in Santa Cruz do Sul, RS, Brazil, with Malaise trap.

\section{MATERIAL AND METHODS}

One specimen (female) was studied. It is housed at Coleção Zoológica do Departamento de Biologia, Universidade de Santa Cruz do Sul, Rio Grande do Sul, Brazil. Terminology used in descriptions follows Fontal-Cazalla et al. (2002). The photographs were taken with a Canon Powershot A 520 adapted to a Leica stereomicroscope (S8APO).

\section{RESULTS}

\section{Zamischus Ashmead}

Zamischus Ashmead 1903a: 221, 1903b: 60, 68; Dalla Torre \& Kieffer 1910: 101; Rohwer \& Fagan 1917: 378; Weld 1921: 437, 1952: 103, 189; Yoshimoto 1971: 979; Díaz 1974: 18.
Type species. Zamischus brasiliensis Ashmead.

Diagnosis. Species of Zamischus, as well as Perischus Weld, 1931 possess a propodeum that is produced posteriorly into a long tapering neck and the metasoma is attached to the propodeum via an elongate slender petiole; the result is an overall long and slender body. In Zamischus, the pronotal plate has two teeth on posterior margin; mesoscutum is smooth, marginal cell of fore wing is open at base as well as on margin, and the petiole is sulcate. In Perischus the posterior margin of the pronotal plate is shallowly emarginate, mesoscutum is transversely striate, marginal cell is closed, and the petiole dull and striate.

Remarks. Zamischus + Perischus lineage which is characterized by a series of striking autapomorphies have few characters providing reliable indications of their affinities to other eucoilines and is possible that many of the Neotropical grade taxa, such as these, represent relictual, morphologically isolated South American linages and that many of the intermediate taxa are now extint, making it difficult to resolve relationships correctly (Fontal-Cazalla et al. 2002; Buffington et al. 2007)

Distribution. Brazil and Argentina.

\section{Zamischus aquilesi Díaz \& Gallardo sp. nov.} (Figs. 1-7)

Female (Fig. 1). Total length $5 \mathrm{~mm}$. General coloration black; mandible reddish brown; fore leg yellowish brown, base of femur and apical tarsal segment darker; mid leg yellowish brown, base of coxa, trocanter, femur and apical tarsal segment darker; tarsal segments of hind leg, except last, 


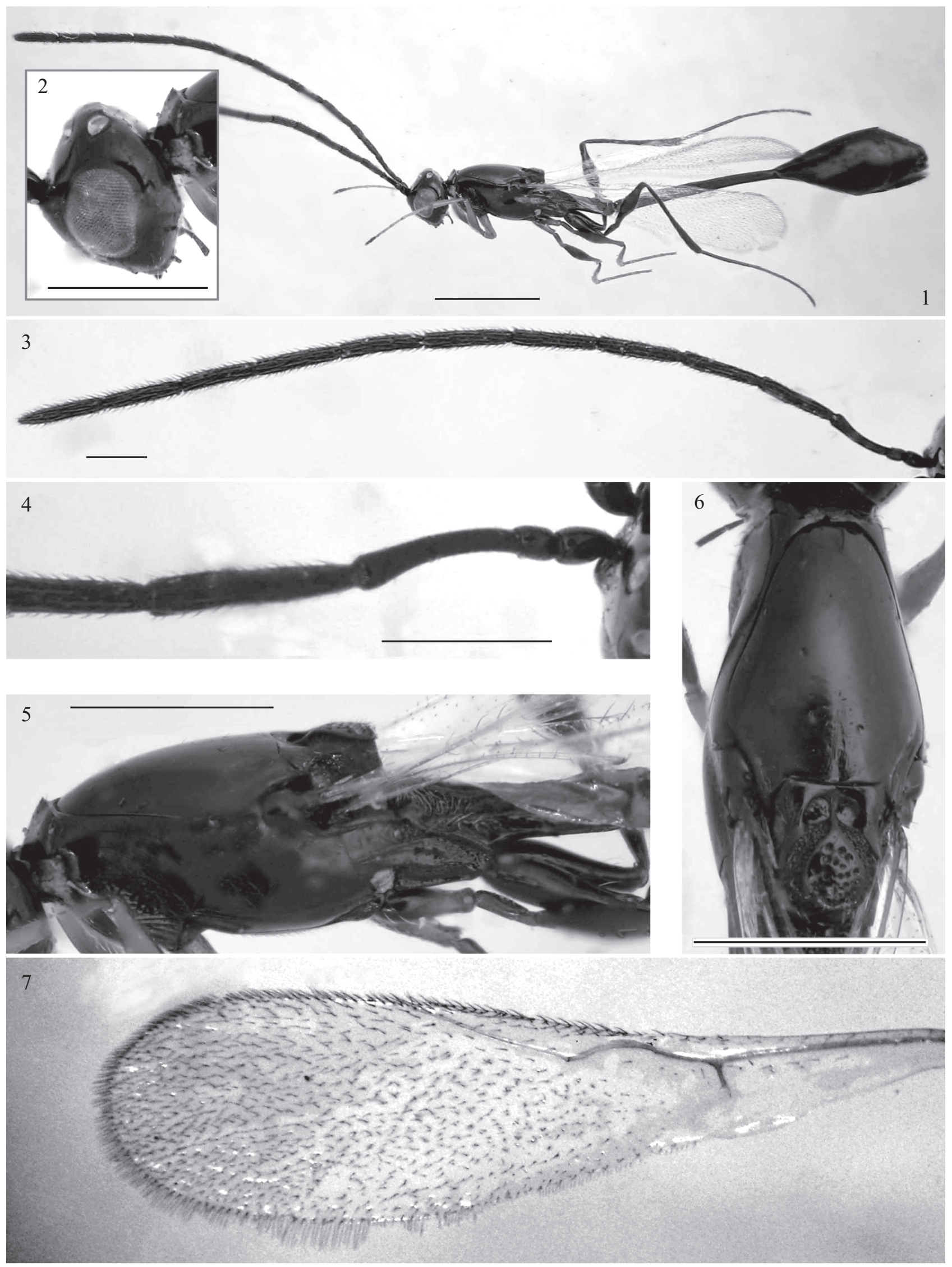

Figs. 1-7. Zamischus aquilesi Díaz \& Gallardo sp. nov. Female: 1, habitus (lateral view) (scale bar, 1mm); 2, head (lateral view); 3, antenna; 4, flagellomeres 1 and 2; 5, mesosoma (lateral view); 6, mesoscutum and scutellum (dorsal view); 7, fore wing. (scale bar, $0.5 \mathrm{~mm}$ ). 
yellowish brown; veins of wing yellow; base of syntergum and hypopygium reddish brown.

Head (Figs. 2-4). Smooth and polished with scattered setiferous punctures on face and genae, broader than thorax, slightly tilted forward and ovate in profile. Gena not margined; malar groove present. Antennae with 11 flagellomeres, filiform, inserted on prominence about middle of face; first flagellomere longer than scape plus pedicel, shorter than second flagellomere, slightly curved, distally swollen, smooth; flagellomeres 2-11 subequal in length, cylindrical, ridged longitudinally, with rhinaria.

Mesosoma (Figs. 5-7). In lateral view longer than high. Pronotal plate smooth, posterior margin with two triangular teeth, slanting anteriorly in diagonal plane (as seen in profile). Sides of pronotum smooth and polished, depression of anterodorsal corner finely striate; highly setose behind genae. Mesoscutum (Fig. 6) smooth, in dorsal view longer than wide; notauli absent; with two pairs of setiferous punctures and a longitudinal depression in the posterior half; parascutal impressions present. Scutellum (Fig. 6) rounded behind; disk minutely punctuate; scutellar plate large, dorsal surface slightly convex, densely punctate, each puncture with single short seta, tapering anteriorly into septum between scutellar fovea, glandular release pit on posterior-facing slope; lateral bars longitudinally striate, length half of scutellum. Mesopleuron smooth, mesopleural carina present. Metapleuron longer than high, with two longitudinal carinae, area between carinae concave, anteroventral cavity conspicuous, setose. Hind coxa cylindrical. Fore wing (Fig. 7) with a single longitudinal vein and basal cross vein; marginal cell long, narrow, open at base and margin; surface sparsely pubescent, margin ciliate. Propodeum as long as the half of petiole; propodeal carinae running along dorsal margin, auxiliary propodeal carinae present; area between propodeal carinae minutely punctate.

Metasoma (Fig. 1). Petiole very long (more than twice the length of the propodeum, 23:10), longitudinally ridged, with two dorsal longitudinal carinae, lesser prominent carinae laterally; gaster short, ovate, laterally compressed, glabrous at base; syntergum present.

Male. Unknown.

Material examined. Holotype. 1 female, UNISC, Brazil: Rio Grande do Sul, Santa Cruz do Sul, 14XII-2009, Malaise trap, Dorfey Coll.

Etymology. Dedicated to Dr. Carlos Aquiles Darrieu (Facultad de Ciencias Naturales y Museo, Universidad Nacional de La Plata, Buenos Aires, Argentina)

Distribution. Brazil: Rio Grande do Sul.

Biology. Host unknown.

Remarks. Female of $Z$. aquilesi sp. nov. is more similar to $Z$. brasiliensis than to $Z$. elongatus. In both species, the petiole is very long and the gaster is short, but the species can be separated from one another by the antennae and scutellar morphology; Z. aquilesi sp. nov. possesses antenna filiform and large densely punctate scutellar plate (antenna widened toward apex and small scutellar plate with peripheral row of setiferous punctures in $Z$. brasiliensis). The female of $Z$. elongatus is separated from $Z$. brasiliensis and $Z$. aquilesi by the presence of a short petiole and elongate gaster.

\section{ACKNOWLEDGEMENTS}

We thank Marta Loiácono, Matthew Buffington and an anonymous reviewer for the critical review of the manuscript, Mariano Lucía for to take the photographs, Cecilia Gorretta and Paulina Hernández for technical support (CIC). Consejo Nacional de Investigaciones Científicas y Técnicas (CONICET), Comisión de Investigaciones Científicas de la Provincia de Buenos Aires (CIC), Universidad Nacional de La Plata (UNLP) - Argentina and Conselho Nacional de Desenvolvimento Científico e Tecnológico (CNPQ) - Brazil, for their constant support.

\section{REFERENCES}

Ashmead, W. H. 1903a. Classification of the gall-wasps and parasitic cynipoids, of the Superfamily Cynipoidea. II. Psyche 10: 59-72.

Ashmead, W. H. 1903b. Some new genera in the Cynipoidea. Proceedings of the Entomological Society of Washington 5: 222.

Buffington, M. L.; J. A. A. Nylander \& J. M. Heraty. 2007. The phylogeny and evolution of Figitidae (Hymenoptera: Cynipoidea). Cladistics 23: 403-431.

Dalla Torre K. \& J. Kieffer. 1910. Cynipoidea. Das Tierreich 24: 1-891.

Díaz, N. B. 1974. Anotaciones sobre cinipoideos argentinos. I. (Hymenoptera). Neotrópica 20: 17-20.

Díaz, N. B.; F. E. Gallardo; A. L. Gaddi; M. Jiménez; P. Ros-Farré; J. ParetasMartínez \& J. Pujade-Villar. 2008. Avances en el conocimiento de las Figitidae Neotropicales (Hymenoptera, Cynipoidea), p. 141-158. In: J. Llorente-Bousquet, J. \& A. Lanteri (eds.). Contribución taxonómica en órdenes de insectos hiperdiversos. Mexico D. F., Las Prensas de Ciencias, UNAM, viii+221 p.

Fontal-Cazalla, F. M.; M. L. Buffington; G. Nordlander; J. Liljeblad; P. Ros-Farré; J. L. Nieves-Aldrey; J. Pujade-Villar \& F. Ronquist. 2002. Phylogeny of the Eucoilinae (Hymenoptera: Cynipoidea: Figitidae). Cladistics 18: 154-199.

Rohwer, S. \& M. Fagan. 1917. The type-species of the genera of the Cynipoidea or the gall wasps and the parasitic cynipoids. Proceedings of the United States National Museum 53: 357-380.

Weld, L. H. 1921. Notes on certain genera of parasitic Cynipidae proposed by Ashmead with descriptions of genotypes. Proceedings of the United States National Museum 59: 433-451.

Weld, L. H. 1931. Additional notes on types with description of a new genus (Hymenoptera: Cynipidae). Proceedings of the Entomological Society of Washington 33: 220-227.

Weld, L. H. 1952. Cynipoidea (Hymenoptera) 1905-1950. Ann Arbor, Privately printed. $351 \mathrm{p}$.

Yoshimoto, C. M. 1971. A new species of the genus Zamischus and description of the male Z. braziliensis (Hymenoptera: Cynipidae: Eucoilinae). The Canadian Entomologist 103: 979-982. 